

\title{
Managing the Transition to Critical Green Growth: The 'Green Growth
}

\section{State'}

\begin{abstract}
Political will at the national and multilateral scale is coalescing around the emerging discourse of Green Growth. The narratives and practices of Green Growth have already been rejected by many stakeholders as a reformulation of business as usual discourse. However, this article argues that this critique is grounded in a false conflation of distinct interpretations of the concept. In place of homogenising all associated narratives, we argue for an aspirational Critical Green Growth perspective, socially inclusive and conducive to structural transformation, incipiently identified in Asian national policies, particularly Korea. Drawing on this background, and other development insights, we conduct a 'backasting' exercise to identify trajectories leading to this imagined future of Green Growth. We address a key gap in the literature, the lack of dialogue between Green Growth and Developmental State studies. We then argue for the importance of the Green Growth State (GGS) in introducing fundamental change in this critical window of opportunity. Elements of this overarching concept would include broad characteristics of: a flexible and diverse policy mix; value-driven, multistakeholder, multi-level governance; public trust and collaboration; and appropriate measurements of progress discouraging commodification of nature.
\end{abstract}


Highlights: (maximum 85 characters, including spaces, per bullet point)

- Identifies the concept of Green Growth as garnering significant national and multilateral political interest.

- Argues that distinct interpretations of Green Growth can be identified.

- Highlights the characteristics of a 'Critical Green Growth' perspective.

- Argues for the importance of a Green Growth State (GGS) in promoting a fundamental transformation in economics.

- Outlines important characteristics of the GGS.

\section{Key Words:}

Green Growth; Discourse; Green Growth State; Industrial Policy; Green Economy. 


\section{Introduction}

"The science is clear: the sponge that cushions and sustains us, our environment, is already saturated with carbon. If we don't limit global warming to two degrees or less we are doomed to a period of unprecedented instability, insecurity and loss of species...As responsible citizens of the world... we have a duty to persuade our leaders to lead us in a new direction" (Desmond Tutu, Archbishop Emeritus of Cape Town [1]]).

At their heart, Green Growth discourses transcend the curbing of economic growth as a means for responding to environmental limits. Green Growth interprets climate change not as a cost, but as an opportunity $[\underline{2}, \underline{3}]$ and advocates investment in the environment as a driver for "recoupling" environmental protection with growth accumulation [4]. For this reason, following its emergence in the West around 2005, Green Growth has gained considerable momentum in supranational organizations such as the World Bank and OECD after 2008 [도, 6]. By 2012, the World Summit (RIO+20) linked the green economy with sustainable development and poverty reduction as priority themes for action, and the UN articulated strong support for Green Growth at the start of the conference.

Despite this momentum however, the Rio+20 witnessed a considerable derailment of traction for the Green Growth. Civil society groups opposed the agenda, with one headline story in the World Summit newspaper Terraviva, boldly pronounced "Green Economy, The New Enemy" [7]. Moreover, the final official conference report, The Future We Want []], contained only a cautious account, with Green Growth as one of a set of important tools available for achieving sustainable development.

In response to what we identify as the non-inevitable stumbling of a potentially powerful paradigm of meaningful transition, the current paper undertakes fundamental reappraisal. We argue the reason for this and other detraction from the Green Growth agenda is conflation with other overlapping, yet distinct and discernible, public policy narratives - the Green Economy and also Green New Deal. Moreover, we identify that in the West, Green 
Growth discourses have become colonised by underlying ideological structures, which utilise selected elements to further more longstanding agendas, such as the continued liberalisation of markets.

As part of this argument we suggest that, while scholars should continue critical treatment of all green Growth discourses and practices, it is essential not to 'throw the baby out with the bath water'. In order to illustrate this, we proposed that the more fundamental constructions of Green Growth as articulated in East Asian, and particularly South Korean which has made astonishing Green progress [2, 9$]$, remain a radical policy alternative for Western transitions. We argue that while a critique of Korea's application of Green Growth might find them wanting against some benchmarks [10], this does not undermine the relevance of original aspirations that contains potential to influence empirical outcomes from discourse formation.

To advance what we term a more Critical Green Growth agenda, the paper fundamentally employs the technique of 'backcasting': first constructing a desirable, aspirational future and then critically exploring the conditions that might potentially precipitate it $[11,12]$. In this way the approach is specifically developed to better embed normative aspirations in the distillation of transformative policy principles and direction $[\underline{13}, \underline{14}]$, and therefore escape confining contemporary discursive fields. Following this methodology, first we build a normative, aspirational definition of Green Growth that transcends current Western interpretations, designed to work as a policy vision or end goal to guide efforts of these coalitions for change. Second, we draw on empirical data and theory to outline an integrative critical perspective depicting conditions needed to achieve such vision.

Overall, the Critical Green Growth perspective that emerges in the first half of the paper supports calls to move beyond the focus of quantitative growth and instead advocates for qualitative change. We support the reframing of economic progress through movement away 
from: quantity to quality, the consumption of physical to non-physical outputs, and technological to wider socially embedded innovation (organisational innovation, social networks and R\&D intensive specialisation) [15]. Practically we argue for the necessity to promote future economic activity not harmful to, and that can support, natural capital. This therefore incorporates quality-oriented, low-carbon, energy efficient growth, with a strong focus on creating value through new clean technology, as well as natural infrastructure and innovation in markets for environmental goods and services. However, we also advocate that existing environmentally problematic sectors of the economy must be proactively phased out. Here Critical Green Growth goes beyond the 'business as usual' perspective that economic expansion should be balanced with proactive efforts to maintain and develop environmental systems - and therefore, engages with central criticism of more mainstream interpretations, such as the Green New Deal [16]. As a result, the quality of Green Growth can be identified by the extent to which 'green' economic activity contributes to enhance and preserve natural capital.

Grounding our 'backcasting' exercise in critical understanding, we build on empirical progress that has been made under the Green Growth agenda in East Asia an specifically South Korea $[\underline{2}, \underline{17]}$. This work identifies a significantly stronger role for the state than has been currently considered in European or North American Green Economy perspectives; and underlies our support for the view that any significant transitional theory must be a theory of politics and the state [18]. The paper therefore addresses a key gap in the literature, the lack of dialogue between Green Growth and Developmental Capitalism State studies [19].

As a result the paper makes unique contribution by proposing the concept of the Green Growth State (GGS) as a value-driven, multi-stakeholder governance framework to facilitate economic expansion from environmentally synergistic sectors; and proactively cure brown operations. Analysing evidence from East Asia, we contend that progress towards a Green 
Growth future will require the institutionalization of deliberative democracy processes - and ecological values transcending national interest as overriding policy principle - in Developmental Capitalism models. In this way, we view our proposals as categorically different from a centralised Green Leviathan model. ${ }^{1}$ Stemming from this core we proposed further characteristics for transformation, namely: (1) a flexible and diverse policy mix, (2) value-driven, multi-stakeholder, multi-level governance, (3) public trust and collaboration, and (4) appropriate measurements of progress.

\section{Green Babies and Brown Bathwater: Deconstructing Green Growth discourse in the West}

The popularity of a new terminology arguably reflects a widespread intuition that something is changing in the structure of society [20]. The term 'Green' has long been associated with environmental activism [21] both grassroots (i.e. Greenpeace) and political (i.e. Green parties), thus signalling a public-private advocacy coalition for transformative social change. However, juxtaposing Green with 'Growth' or 'Economy', signals that society is recognised that ecological and economic problems are inextricable linked. Green Growth as a semiotic unit encapsulates this much more fundamentally and succinctly than sustainability, resilience, resource-efficient or "low carb" (which does not account for waste or exhaustion of resources). While we recognise that some interest groups might outright reject associations with 'Green',

\footnotetext{
${ }^{1}$ The Green Leviathan perspective argues that centralized national-state level environmental policy produces more stringent regulation and delivers more effective environmental protection outcomes that devolution and decentralized policies. Using empirical evidence from US, Canada, Switzerland and EU, Weibut [20] demonstrates that when formal and informal cooperation between state or provincial government were tried, they proved less effective at environmental protection than national standards, He argues that, in particular, regulatory enforcement provisions must be centralised and not subject to negotiation in order to be effective.
} 
the above logical coupled with the extent adoption of Green Growth well supports efforts to work with a normative built around the concept.

Taking this forward, an examination of academic papers referring to the term Green Growth in a discussion of new economy discourses $[\underline{19}, \underline{21}, \underline{22}]$ identifies an inevitable variety of discourses; many of them, we argue, antithetical to its roots. More importantly, many interpretations of Green Growth reformulate underlying framings. As a result, subsequent critical engagement largely covers old ground with critique, as in the case of Rio+20 objections, stemming largely from underlying manipulations. For example, in many cases Green Growth is interpreted as free market environmentalism and used to continue advocacy for neoliberal policy and governance tools [23]. Here detractors respond with reference to growing inequality, market failures, focusing on the continuation of economic colonialism and resource extraction [19]. In other places, Green Growth is interpreted as narrow sustainability, with criticisms focused on a lack of attention to social inclusion [24]. In some cases, Green Growth provides a guise for weak sustainability or ecological modernization [21], and to advocate the monetization of natural capital, technological solutions and human ingenuity. Here criticisms identify failures to recognise the physical limits of Earth and customers' responsibility; thus increasing reckless behaviour, weakening the precautionary principle and hindering political space for more radical transformation [25, 26]. Similarly critics of framing as low carb, resource-efficient or green developmental growth point out that these are all too prosaic approaches. They assume that only incremental changes are needed but fail to address the real extent of interconnections and complexity of relations between political, economic and ecological structures. When Green Growth is taken to mean Green Developmentalism its application is narrowly prescribed as a strategy useful only for natural resources rich countries in the initial stages of development [24]. 
Based on this analysis, we are argue that while the critique of emerging Green Growth discourses is important, it is not analytically helpful to treat the emergent concept of Green Growth as a mere conduct to bring longstanding debates to the fore. Moreover, the rejection of certain interpretations does not detract from the value of more fundamental and critical meanings; and here we assert the importance of disseminating a more historicised interpretation, much more radical in its construction.

For us, a dominant but largely overlooked feature of Green Growth is its non-Western, peripheral provenance. When endorsed by the 5th Ministerial Conference on Environment and Development in Asia and the Pacific (MCED-5) the allure of the concept lied in the simplicity of its definition: inclusive growth that is created by expansion of green sectors and transformational greening of the economy. Greening was about reducing the carbon intensity of an economy that was less polluting and wasteful, but more resource-efficient. The main drive was "national interest" to address climate change and energy security while pursuing the competitive advantage of Asian multinationals by creating a new growth engine for the region (becoming a "World Green Power") [르, 28]. Green Growth was also explicitly socially inclusive and should convey "a green revolution of improving the quality of life for all" [29]. For civil society, the term evoked ingrained cultural values of harmony with nature.

Arguably, the widespread dissemination of the term had been only possible in the context of globalized world economy and the slow shift in geopolitical power from West/North to East South. However, being an "alien" concept to western approaches, its appropriation by western actors substituted Asian values for western blueprints, in what can be seen as a process of assimilation to dominant value systems (cultural colonialism). In such a process actors make sense of an alien concept by association with existing debates, superimposing their own biases and cultural judgements. In western contexts Growth has been long framed as an end on itself: 
social and environmental aspects relegated in the assumption that eventually growth will spillover and markets will provide solutions.

From these Western reconfigurations emerge concerns, such as those of Atkisson [24], about the exclusion of social issues from green growth saying that Sustainability is Green Growth + Welbeing. Moreover, that Green Growth is inferior to sustainable development since a "A thing may be considered green (a super-efficient, low-emissions diesel car, for example) without meeting the real criteria for sustainability: fitting within the resource and ecosystem capacities of the planet (aka the 'planetary boundaries'), while being universally accessible, theoretically, over time, to all people" [24]. However, such concerns arise from the reconfiguration of discourse in the transition from Asian to Western contexts. Growth in East Asia is not an end in itself, and has been much more closely associated with equity promoting mechanisms. The Asian Tigers achieved an unparalleled growth with simultaneous reduction of inequality and progressive democratization from 1960 to 1990. This was reflected in what East Asian countries termed the "principle of shared growth" [30]. South Korea assumes that endurable growth is inclusive; and the novelty of Green Growth in the Asian context is that now growth also needs to be green, reflecting human-nature harmony. The current narrative in Korea's government reflects this clearly: Green Growth is the answer to three fundamental challenges: Energy Security, Social Inclusion and Environmental deterioration. Green Growth implies a process of transformation of the economy and industrial structure to make it more efficient, clean and de-coupled from exploitation of natural resources; and this is well illustrated by Koreas progress in reduced dependence on oil [31] carbon intensity [2] and improved energy efficiency [32].

\section{Critical Green Growth: An aspirational interpretation}


Many elements of the Korean critical perspective have been incorporated in "The Future We want", leading Meadowcroft - one of the pioneers of strong sustainable development - to conclude that "There is a level of engagement with ideas of limits, and a concern with adapting the human economy to operate within ecological constraints, that in some ways extends beyond where these organizations have been before" [33]. However, there are also contradictions, inconsistencies, a reluctance to explore conflicts, and diverging currents affecting the coherence of critical Green Growth narrative; therefore threatening to make it misleading, evasive and constraining [34].

Here we agree that Green Growth should include not only social inclusion and transformative intent (already contained in critical views), but also an explicit position with regards to changes in consumption patterns and lifestyle [26, 35], commodification of nature $[\underline{36}, \underline{37}]$, substitutability of types of capital and co-existence of green and brown economies. Our position is that natural and cultural capital cannot be replaced or duplicated by man-made capital. There is an intrinsic value in nature that cannot be measured in economic terms because it is independent of human needs. Although unmeasurable, the richness and diversity of life forms contribute to sustain human civilization and values in ways we still not fully understand [33]. Moreover, ecological losses are frequently irreversible and the impact of its loss in human life hard to assess ex-ante [38] Commodification on nature increases the risks of making the wrong decisions about nature. Rather than protecting nature by giving it a price, nature should be protected by reinforcing values of moral duty and affectedness reinforcing the uniqueness and intrinsic value of life supporting systems and the moral duty to live in harmony with nature.

Although Green Economies have long included a consideration of environmental issues [39] the main drivers for Green Growth are not only ecological but also economic, social and technical. Green Growth is proposed as a post-financial remedy to reinvigorate the ailing global economy, refocusing it towards being more socially inclusive through investment in markets 
for environmental goods and services, and the development of natural infrastructure, and capital, such as forests, water bodies and bio-diversity [40]. In this respect, Green Growth breaks from the Kyoto process which signalled restraint in the growth agenda and instead emphasises business opportunities, enterprise and job creation [41]. For example, South Africa's Working for Water Program, which has created 25,000 new jobs for the unemployed in the removal of invasive plant species that consume high levels of water, and the Kibera Community Youth Program in Nairobi, which involves unemployed youths in the assembly of small and affordable solar panels [42].

Green Growth is not meant to be an extension of the Ecological Modernization discourse [43, 44], whose technical-economic focus aims only at improving environmental efficiency to maximize profit while minimizing environmental costs [45]. Instead gamechanging, Critical Green Growth must be fundamentally rooted in economic approaches allowing for the inherent complexity of human-environment relationships. Critical Green Growth is to be fuelled by policies and managerial techniques promoting synergies - rather than just decoupling - environment and traditional business ${ }^{2}$. To achieve this aspirational vision is not enough having a expanding green sector, but also pro-actively phasing out traditional "brown economy" and chaging consumption patterns and lifestyle. Green Growth is a combination of growth in "green , smart sectors" and degrowth in "brown, inefficient sectors" [15]. The idea of creative destruction in which new forms and ideas drive out the old is central to this process [48].

Reflecting how accumulation of growth translates into Green Growth principles, suggest that Critical Green Growth discourse should shift concentration away from the quantity of growth, towards a quality of growth amalgamated from consumption of physical and non-

\footnotetext{
${ }^{2}$ For fuller discussions of the relationship between Green Growth and previous sustainability paradigms see Glemarec and Puppim de Oliveira [46] and Vazquez-Brust and Sarkis [47].
} 
physical outputs (i.e. services and experiences), and from the production of environmentally harmful goods and services to those that are environmentally enhancing [49]. Moreover, 'environmental industries' are to include technological sectors which combine low-input, low entropy and low waste characteristics. Green Growth accepts the assumption that a fundamental transition away from Green House Gas (GHG) intensive energy sources is a matter of urgency. Policy makers must move beyond consideration of the physical availability of carbon based fuel sources. Instead, the true concern must be the decline in "the capacity of air, water, soil, and biota to absorb, with intolerable consequences for human wellbeing, the effects of energy extraction, transportation and use" in addition to the political stability to maintain the current status quo [50].

Consolidation of Growth systems should relate to interventions aimed to make sure that although Green Growth adds value(s) to the economy, it does so in order to identify virtuous cycles, consolidating networks necessary for a circular economy, coordinating global learning curves for green technology and a market for resources with emphasis on recirculation rather than wasteful linear throughput [51], while seriously considering the need to invest in measures that prevent a major spike in energy prices, and thus significantly endanger national, regional and global economic activity.

Allocation of Growth must be carefully monitored by governments. Critical Green Growth discourse also expects economies to be socially innovative in providing the basis for socially just and inclusive growth. Thus, there must be behavioural transitions to slow anthropogenic causes of climate change and trigger both high-skill intensive employment R\&D in clean energy technologies - and low-skill intensive employment - for instance in forest planting, and organic agriculture. Inclusive growth is not only a long-term objective. It is also argued that green public and private spending is a better and more inclusive than "brown" 
spending, when seeking to reactivate economies in a recession ${ }^{3}$. Many environmental measures related to construction and resource management activities, such as making buildings more energy-efficient, are not only labour intensive but also location-specific and not practical candidates for off-shoring [52]. As the discussions in the next section highlight, social justice considerations must be maintained at both the national and transnational scale as fundamental part of the Critical Green Growth approach.

However, despite the identification of an aspirational discourse of Green Growth, the underlying question becomes how to manage the process to ensure that 'creative destruction' results in Green Growth? The metaphors is a garden where valuable plants must be nurtured but weeds extirped. But, who is the gardener in this metaphor?

\section{Who will be the Gardener? The imperative of the 'Green Growth State'}

To better understand how the aspirational vision of Green Growth can be achieved in a timeline that accounts for the urgency of climate change challenges, we draw on the World Banks’s functional approach to understanding rapid growthb (FAURG) ${ }^{4}$. FAURG links rapid growth to the attainment of three functions of growth: accumulation, efficient allocation and rapid technological catch up. The current interconectednes of the global economy calls for a

\footnotetext{
${ }^{3}$ This view is often called "Green Keynesiasm" [16]. In a recession governments must compensate loss of private consumption with public spending. Green stimulus offers competitive advantages over traditional sectors' spending: resource efficiency liberates resources for firms and customers to spend elsewhere, pollution control and climate change action has spill-over health, amenities and catastrophe-prevention effects; advancing investment due for the future by replacing ageing infrastructure with green infrastructure (i.e. transmission lines) has larger stimulatory effect and better cost-benefit results in the present than in the future, since it benefits from cheaper resources available in a recession [52].

${ }^{4}$ The approach was developed by a World Bank team led by MacDonald including Nobel-prize winner Joseph Stiglitz [30]. The objective was to find a theoretical basis for the unprecedented growth with decrease of inequality achieved by 8 high performing Asian Economies from 1960-1990.
} 
further attribute of growth, particularly relevant to achieve green objectives: the consolidation of growth systems across national boundaries (i.e global supply chains, alliances, etc).

The neoclasical views argues that markets perform the allocation function more efficiently than agents. However, FAUG observes that markets have consistently failed to allocate resources appropiately in earlier stages of developments when economies transition from agrarian to industrial. Building on this, we aregue that as coordination needs characterise early stages of any socio-technical transition, markets will be ineficcient in the intial stage of transitions from "brown " to "green"; and even more when the nature of environmental challenges represents a global collective action problem where coordinated actions and agreed principles are needed across a range of actors [53]. Studies on innovation and societal change show that uncoordinated initiatives are not the way "to get the ball rolling and to "learn by doing' [54] and global markests underinvest in the formation of economic and technological networks that increase innovation and productivity. [36]. R\&D and new network creation, such as distributed energy systems, requires state driven innovation and network creation with positive effects on economic growth in general [55].

In the East Asian miracle, the solution to coordination failures was government intervention to go beyong market based competition and emphasise cooperative behaviour among private firms (and among firms and givernment) and clear, performance-based standards of success. The key feature then, was evaluation of results, with the government distributing resources on the basis of performance, which the government and companies jointly monitor. Moreover, the recent emergence of Green Growth policy discourses has been matched with public investment, for example through recent stimulus packages in countries such as South Korea and Malaysia, in green sectors. [ $\underline{56}, \underline{57]}$. This is of course contrasted with alternaitve approaches in other countries, where a diluted Green agenda has seen less signifcant 
green investment and indeed a relaxation of environmental regulation, for example in China $[\underline{58}, \underline{59}]$, where anlaysis rightly finds shortfalls in the greenign fo the economy [60].

Although mass behavioural change is best facilitated through market price setting, the potential of environmental limits cannot be downplayed, for which maintaining welfare will be considerably more costly to the global economy if these limits are pushed [61]. For this reason, there is a need to work within existing state structures but to bolster the state's involvement in setting the parameters on private freedoms as coordinated by market governance and incentivize and coordinate the achievement of social cohesion through Green Growth policy. In order to do this, the state must 1) adopt the explicit objective to direct socially just qualitative development through the facilitation of Green Growth; and 2) continue to enfranchise those in both current and future generations affected by environmental degradation (discussed below). These two factors together will facilitate the transformation of the state from the Liberal Democratic to "a post-liberal, rather than anti-liberal” [62], 'Green Growth State' (GGS).

The importance of situating Green Growth in the very DNA of the nation state is not just grounded in logical or ideological ideals. Firstly, successful initiatives that achieve good results can be stopped by changes in governments and the interests affected by these changes [46]. Thus, it is necessary to institutionalize anthropocentric, intergenerational commitments of social justice, as mediated by environment stewardship, at the constitutional level - as has been undertaken by the national administration of Wales in the United Kingdom [63]. Late developers who have achieved most in terms of qualitative development can be defined 'Developmental Capitalism States' [64-66], who have development and social cohesion, not economic growth, as their primary goals. For example, the Asian Tiger Economies (South Korea, Taiwan, Singapore, Hong Kong) have embodied significant state directed growth but also achieved equitable distribution and other positive indicators of human development [67, 68]. 
Environmental commitments must extend through government institutions into regional strategies and especially individual cities, which have a multitude of policy tools to embed Green Growth thinking $[\underline{69}]^{5}$. While the translation from policy to action cannot be assumed, depth and density of concrete commitment is an essential starting point for Green Growth transition. For example, these commitments are evident in the case of European green energy, where clear political aims have been instrumental in driving markets, technology or civic mobilization [70]. Overall, GGS should intentionally foster a situation of "embedded autonomy" - and return to this topic later in the paper. Now the four major elements of GGS are presented and include: flexible policy mix; value-driven multi-stakeholder, multilevel governance; public-private collaboration; and measurement of progress.

\subsection{Flexible Policy Mix}

Governance frameworks capable of facilitating desired development trajectories are a fundamental issues. Bold governments stimulate private spending by creating certainty about future green markets using a mix of policies, such as pricing, regulation and institutional reform [71]. The economic achievements of developmentally successful countries have been based on pragmatic approaches to governance, emphasising the importance of reflexive and dynamic systems. Historically, European and North American nation states adopted a central role in guiding market activity, well before liberalisation further promoted market governed efficiencies [72]. More recent examples of high growth (e.g. South Korea, Taiwan, Brazil) are also characterised by strong levels of state intervention before liberalisation is undertaken [국. The current state's role in rewarding finance on the basis of performance is an integral means

\footnotetext{
${ }^{5}$ Such as a) greener public services and purchasing behaviour, b) eco-efficiency of industrial production, c) consumer awareness and demand incentives, as well as d) support for research and innovative applications of green technologies.
} 
to promote compliance of private firms in advancing the competitiveness of domestic industries $[\underline{74}, \underline{75}]$. Drawing on comparative capitalism analysis [다], it is argued that stronger levels of government intervention to compensate market mechanism imperfections, give more opportunity for rapid "greened". Thus, transition to Critical Green Growth is likely to be easier under models of social-market capitalism and developmental capitalism, where key attention is paid to 'industrial policy' $[\underline{77}, \underline{78}]$ and a great degree of social accountability of business and ideological emphasis on values other than economic efficiency. The progress made by Korea and Malaysia in the development and implementation of their Green Growth, or Green Industrial policies can be seen as early evidence in support of this point [2].

Given this situation, GGS must apply an appropriately sequenced, flexible and diverse policy mix, drawing on both price and non-price policy tools in order to appropriately structure both demand and supply [국. Policy must intervene in market operations 1) to sharpen incentives for the fulfilment of their Critical Green Growth agenda; 2) synchronise the disincentives to products and processes that undermine long-term living and production conditions [ $[\underline{80}$, and 3) steer the more sustainable trajectories of innovation in situations of technological bifurcation when there is a market stand-off between alternative technological trajectories $[\underline{81}]$.

For universal issues, market governance offers low transaction costs given its ability to coordinate millions of individual actors in both daily and less frequent activities. Unstructured markets facilitate actions that degrade ecosystems, because as they are unable to sustainably manage open-access resources such as the communal atmosphere. Therefore markets require scaffolding and structuring institutions, and the GGS must take a fundamental role in establishing these frameworks [46]. For example, price policy tools encompass a variety of economic instruments such as environmentally-related taxes, fees, charges and the elimination of environmentally harmful subsidies [47]. Within this context, GGSs should consider 
facilitating the development of a generic carbon tax and/or emission trading scheme in order to send a clear market signal to incentivise a wholesale transition from high to low carbon intensive economic activity and technology $[\underline{40}, \underline{82}]$. Disincentivising environmental damaging activities alone is likely to hurt economic growth, to counteract these constraining policies, positive price incentives to compensate for this in other areas is recommended [41].

As a specific case, renewable energy has become a major field of green entrepreneurship [41] and in the European Union has been stimulated by targets for renewable electricity to make up $21 \%$ of supply by 2010 (Directive 2001/77/EC). In response, EU Member States introduced a variety of policies and support schemes, in the case of Germany and Denmark moving policy out of traditional silos and resulting in industry development and job creation [83]. Broadly, green energy technologies can be seen as highly disruptive technologies in that they reconfigure socio-technical systems by allowing both large and small consumers to become involved in production, and where bottom-up growth builds a more balanced multi-level system [84].

A reflexive and flexible approach is further supported because GGS must also take action on removing environmentally damaging economic activities. Non-price policy tools including: command-and-control regulations; voluntary approaches based on negotiated agreements between the government and specific industrial sectors to address particular environmental challenges; and government stimulus for green technology innovation (training, network formation and research) can all be utilized. The latter tool is exemplified by the following: Korea used $79 \%$ of economic stimulus for its green economy; the EU $59 \%$ and China $38 \%$, and the US allocated $12 \%$ [85]. Note that only Korea's case can be considered aligned with Critical Green Growth. All the other countries invested more in sustaining their brown industries than in promoting green ones. 
At the level of policy specific requirements, a key issue will be prioritising investment in appropriate education and training in, for example, how universities contribute to a labour force with multi-functional and high competencies for innovation within a Green Growth economy [무].

In order to establish appropriate non-price interventions, it will require information about: what threshold should be applied to define low-carbon; what resources are nonrenewable; what is 'non-sustainable intensity'; as well as the application of life-cycle analysis to understand true net effects of any interventions. In Japan, for example, although nuclear production was initially part of the 'New National Energy Strategy', the Fukushima disaster (March 2011) was interpreted by some to rule out nuclear activities. More broadly the role of nuclear energy in the delivery of Green Growth has been strongly questioned [87]. A further point is that regulations might also be necessary to complement stimulus packages to environmentally enhancing economic sectors [88]. Providing incentive structures necessary to support entrepreneurs and improve competitiveness is one policy avenue [89].

Another significant policy instrument is the restructuring of public procurement guidelines to consider environmental issues. This possibility has been adopted in Korea [2] and in the European Union [90]. Naturally, blanket regulation will be controversial and a localised approach taken into account local conditions is more appropriate. For example, while strong regulation might be attractive, over-assertive policy measures taken too early may lead to blockage, as vested interests in the carbon economy resist loss of status quo [41]. In many cases then, softer and less confrontational policies with triggering effects may have a better chance of success [70].

In today's globalised economy, no single nation can achieve Green Growth goals with policy contained entirely within the country's borders: although, different approach may need to be taken in different states given contrasting internal characteristics. The republic of Korea, 
as a case in point, is helping Mongolia and Vietnam, find and implement their own green growth strategies, tailored to their specific needs and conditions [24]. While the European Union, for example, in the area of green energy policy, shows that in place of prescribing one universal set of policy tools across member states, the details of the GGS are better worked out within national contexts. Success depends on the respective framework conditions in the individual Member State and the specific style policy instruments used [91]. Empirical evidence collected in EU-15 states by Damonte [92] support the effectiveness of tailoring elements of a wide policy mix to each country's idiosyncrasies. Countries will therefore need to find the right policy-mix for their local context while meeting the needs of international markets. Such a policy mix, should also identify and support the best green technology platforms to leverage comparative endowment advantages and foster international competitiveness in selected environmental goods and services. Results can be obtained using different tools provided that evaluation is used to keep tools harnessed to this policy goal [92, 93].

\subsection{Value-driven Multi-Stakeholder, Multi-Level Governance}

The ultimate ability of liberal democratic governments to resolve, rather than manage ecological problems has been strongly questioned [62 see Chapter 4]. Therefore, in order to escape derailment by economic (neo)liberals the GGSs must expand national and international institutions of participatory governance through which policy debate can be directed. This need is also supported by the limitations of the Korean example. Here government failure or unwillingness to involve local actors and communities is found to result in a lack of wider pressure on companies, who have more recently retracted support for Green Growth given declining profit motivations $[\underline{19}, \underline{28}]$. 
There is an overwhelming need for increasingly participatory spaces for debate despite the required strength of the GGS. This need for further participatory debate is due to the need to foster domestic societal trust and participation, and overcome a lack of international governance. Transformation requires evolution not revolution, the further enfranchisement of stakeholders affected by environmental damage must be a key feature of the GGS. Political participation is in itself a desirable development aspiration [94], and that reflexive policy can only emerge through stakeholder participation - a characteristic that also builds the important element of trust and collaboration which is further elaborated below.

Currently, the liberal democratic state only provides formal and not substantive freedom for citizens to operationalise their own concept of the 'good life'. This provision will require two interconnected changes. The first is the adoption of Critical Green Growth as the central mission of state operation. The second is the development of participatory processes beyond only those currently holding power and to further encompass wider communities of the environmentally affected and their representatives. The GGS needs to integrate the principle of common ecological embeddedness and affectedness to include those greatly affected by Green Growth policy decisions. This will necessarily include an expansion of participatory institutions at both the intra- and inter-generational scale. In agreement with many philosophers of green politics, the rule of law and principles of democratic oversights must therefore not only remain, but find themselves strengthened through post-liberal reform.

This argument draws on the position of as Habermas [95] who highlights the importance of structuring collective identity, not around the common culture of the nation state, but around shared democratic procedures. However, a pragmatic approach also recognises that institutional development must accept the existing role of institutions comprising the nationstate: and we agree with Dryzek [43] that the best bargain is likely to emerge from the reconciliation of state interests and defining movements. In this respect the construction of the 
GGS should deepen deliberative democracy while avoiding the trap of conflating this with positive environmental outcomes [96]. Deliberative democracy includes the use of dialogue and reasoned argumentation to foster mutual understanding, delivering collective decisionmaking through the best possible genuine democratic decisions, reflecting the diversity of interests and minimising the interference of political power, money or strategising [43]. The practical realisation of this theoretical underpinning is an increased density of multi-level and multi-dimensional governance, which includes vertically different levels of government and horizontally across networks across sectors, regions and stakeholders [41]. Furthermore, this process of institution building must take place both below and above existing national governments. It is for this reason that many see the development of meta-governance as an important mechanism for sustainability issues [97]. In terms of innovation, this approach challenges the assumption that the poor are too poor to eco-innovate. It also argues that multilevel governance should promote grassroots eco-innovation as an avenue for inclusive Green Growth exploiting local potential, traditional knowledge and international connections [98, 99]. These differing levels are discussed in the next two subsections.

\subsubsection{Sub-National Governments}

In complement to our proposal to embed Green Growth as the principle mission of government, some suggest a charter of citizens' environmental rights and responsibilities be appended to existing civil and political rights [62]. For example, in contrast to popular perceptions, China has made substantial progress on granting and enforcing the public right to environmental information [100]. Given the importance of international cooperation on these issues, multilateral agreements could be developed to encourage states to offer similar rights. This cooperation is exemplified by the Aarhus Convention (2001) that grants access to information, public participation and justice, in governmental decision-making concerned with the local, national and transboundary environment. The role of local authorities is already well 
recognised by national signatories of UN's promotion of the Agenda 21 initiative, although further work in making them accessible to communities and their representatives would be essential. One practical suggestion is that representatives of environmental NGOs could be given more direct access to decision making processes at this lower levels of national government [62].

Aside from state initiatives, both informal and formalized networks and coalitions have been established between cities and regions, such as "Cities for Climate Protection", "Climate Alliance', and the C-40 "Large Cities Climate Leadership Group'. One area of particular interest is sub-national networks for the planning of more environmentally benign food systems, particular geared around the issue of nutritionally and quality based urban food security [101].

Alongside, regional governance, alternative institutions to open up access to state power include community-right-to-know, community environmental monitoring and reporting, third party litigation rights, environmental and technological impact assessment, statutory policy advisor committees, citizens juries, consensus conferences, and public environmental inquiries [62].

\subsubsection{National Governments and Above}

In many cases national or regional economies have become greener by simply exporting negative environmental activities to other regions of the world, often with less capacity for regulation or alternative operation, therefore greatly hindering global Green Growth. This has been defined as the pollution haven hypothesis. In this context, national regulations are increasingly impotent for regulating cross-border supply chains [102] [103]..

Although case studies, in which one region is found to impart negative environmental impact on others $[\underline{104}, \underline{105}]$ are criticised as failing to account for the system as a whole - as in the case of global forest destruction [106] - coordinated efforts are still needed to keep 
positive developments on-track and precipitate change where global balance is less certain for example in the area of fish stocks [107] or ground water [108]. In response to this need, the development of international multilateral agreements between states offers one well tested means of creating "over-lapping, supplementary structures of rule that actively utilise existing territorial governance structures" [62].

The necessity of state lead national and supranational coordination is grounded in three arguments [54]. First, transitions from fossil fuels to renewable-energy sources need organizational innovation and transformation requiring several decades, speeding up the process needs international focus and coordination. Second, international coordination is necessary to develop Global Learning curves for creating energy-efficient and renewableenergy technologies. Third, international coordination will be necessary to overcome the resistance to change in incumbent production and consumption systems,

The experience of the European Union provides important lessons into the possibilities of building supranational governance institutions. Particular examples include the significant achievements in environmental policy through the involvement of a variety of state and nonstate actors at different levels of governance, ranging from the local to the global [109]. These state backed institutions are an important future development given the limited life span and impact of ad-hoc agreements such as the Kyoto Protocol [요]..

Beyond these developments radical proposals for new forms of global governance, including global parliaments, an interconnected global legal and court system, an international military and guaranteed basic income have been recommended [110]. Many see the United Nations as a natural starting point for the reform of global governance [111].

However, radical multilateral agreements are likely to be hampered by "trust deficits". These trust deficits include the lack of trust between countries created by historical patterns of confrontation or exploitation. Trust deficits are rooted in the principle of belonging and require 
time and continued effort to build bridges and connectivity. Therefore, a reflexive component makes it possible to transnationalise democracy in adaptive, incremental, experimental, consensual, and domain-relative ways [62]. These projects would entail adding, qualifying, and supplementing the principle of 'belonging', with the principle of 'affectedness' [62]. Innovative suggestions scattered throughout the literature on green governance might prove of interest. For example, Thompson [112] proposes non-citizen Tribunes where representatives of ordinary foreign citizens and international organisations can participate in decision making as a means to open up the conventional international discussions between states. Other ways of developing governance frameworks that transcend the boundaries of nation state jurisdictions might be deliberative forums for discussion, reciprocal bilateral representation in decision making processes and cross-border referenda.

Participatory governance at any level offers entrenched interests the opportunity to resist change. For example, "reforms to remove subsidies on agricultural inputs and fossil fuels are not only frequently opposed by multinational oil companies as eating into their profits but also by the poor who rely on the subsidies for their basic needs" [46]. In this sense, the GGS must ensure appropriate sequencing of policy that interacts with actor's capability to accept and complete difficult transitions; with important differentiation between concessions for stakeholders fundamental and more peripheral to the continuation of problematic trajectories.

\subsubsection{Public-Private Collaboration}

Not only does a Green Growth future require dynamic interaction of competition-based incentives, but also collaboration and cooperation by networks of private firms and public institutions [113]. Although the illustrative examples of East Asian development and Green Growth have initially employed very strong state interventions (although the extent of this 
intervention in some areas has been reduced over time [114]), ideological emphasis placed great priority on 'social cohesion' as a main objective of economic development [115].

These issues bring into question the conclusion that Green Growth is similar to other policy reforms advocating the acceptance of short-term investment costs in the expectation of long-term gains [116]. In Korea for example, the development of the Green Growth agenda has been underpinned by a continuation of a strong government direction, but an overt concern for social cohesion and distributive justice, which is evidenced by the universal energy service for the poor under which government has been made responsible for eradicating energy poverty by 2016 [103]..

One of the key characteristics of the successful development state model was the "embedded autonomy" observed between the state and wider society [117]. According to this analysis, successful developmental capitalism states require "corporate coherence" - among state officials in their commitment to the goals of the state - and connectedness to groups in civil society - including both developmental elites and community/neighbourhood representatives. This approach recognises the importance of "interdependent networks" in both facilitating and impeding the greening process [118]. Just as an entirely green culture might not be necessary to for green reforms within a particular firm, the key to wider transition is more likely to be appropriate interdependent networks of individuals in key positions. The Korean GGS, exemplifies this situation, where the Presidential Committee on Green Growth (PCGG) was drawn from governmental ministries and the private sector [2, 103].Indeed, Evans, who developed this characterisation of Asian governance initially focused on industrial development [117], his later work increasingly considered "sustainability" [119]. While it might be assumed that private interest will feed into government processes, with strong state commitment, it is also expected that the reverse will be true. In this way, networks embedded 
with eco-centric "sense-making" resources can offer beneficial spill-overs into other networks and organisations [120].

However, pubic private collaboration needs to be balanced with wider societal embedding to avoid capture of the state by business interests. This need is illustrated by more recent gridlock in the traction of the Korean Green Growth agenda. After initial support, private companies later moved to oppose the speed of economic greening; refusing to invest in renewables, opposing the introduction of ETS and the compulsory use of the Governments Mandatory Environmental Management System [28]. Wider public involvement and governance would help offset this to some extent we argue.

\subsection{Measurement of Progress}

Without integrated indicators for environmental and economic policies, economic transformation will remain rhetorical [121]. "If we have the wrong metrics, we will strive for the wrong things [122]. Uni-dimensional Gross Domestic Product (GDP) metric leads decision-makers to sacrifice natural resources and ecological environment to achieve economic development [122]. However, it is also true that decades of efforts to adjust the primary metrics of developmental evaluation [123] have made little impact on the way that the mainstream economy reports 'success'.

Despite this inertia, reform in the light of new normative values emerging within the Green Growth paradigm is necessary, as it is important that we measure what we care about [124]. For this reason it is suggested that Critical Green Growth has the potential to overcome the current impasse. Previous efforts to rethink quantitative evaluation have gained little traction as they have focused on discounting GDP, or offered only vague measurements and use of indicators [125]. Alternatively, Green GDP would assign more weight to environmentally enhancing goods - those products and services that preserve and develop 
natural capital - and account for future effects of current investment trends [See for example: 126]. Other complimentary indicators might also be useful, such as Greenhouse gas emissions per unit of value added (GEVA) for example [127].

In addition to a reformed system of national accounting, individual businesses and organisations will also need to reform their matrix of evaluation and other descriptive indicators. The UNDP [128] suggests focusing development on the areas of economic transformation, resource efficiency and progress and well-being. If such measurement is to be operationalised however, international forums will have to agree on standards and disclosure of environmental information along global supply chains. It will also be important to recognise that measuring green transition requires an appropriate timeframe: as although President Park has placed reform of Korea's energy policies and industrial infrastructure as a top priorities, outcomes are only likely to emerge in the medium to long term future [31]. Whatever the indicators taken to benchmark progress, ideally ecological evaluations will become as normal as conventional economic terms presently used in decisions [129].

\section{Conclusion}

Overall, this article has highlighted the emerging policy discourses and practices associated with the term Green Growth, and argued for the importance of maintaining the more critical/radical interpretations. Most fundamentally, we argue that for such a radical approach to emerge, the Green Growth State (GGS) will be required to manage a convergence between the western liberal and Development State models to situate Green Growth as the central aim of multilevel governance arrangements.

Summarising the existing discourse Critical Green Growth needs to move beyond ecocentric perspectives of previous sustainability paradigms that call for a contraction or steadying 
of economic activity. However, the critical interpretation also avoids ecologically weaker perspectives of the Green Economy. Although it advocates the addition of value(s) through expanding green activities - and therefore places the emphasis on the qualitative quality of growth as opposed to simply the quantitative element - it also seeks to proactively curb environmentally damaging economic activities. The strong economic focus of Green Growth seeks to establish virtuous cycles as expansion in green sectors creates other opportunities in the economy, principle of which are green sector jobs for the population. To maintain the anthropocentric nature of the sustainability agenda, Critical Green Growth also maintains a focus on social justice to promote more equal forms of development in the current and future generations.

In order to help precipitate this desired outcome, it has been suggested that the state take Green Growth as its defining objective, from which can stem a flexible and heterogeneous policy mix to achieve this. While the appropriate model for the governance to structure any activity is always controversial, we have drawn on our view that the most paradigmatic successful examples of developmental transition have been centrally precipitated by the nation state. Initially, this has involved more direct and dense intervention, although as the private sector has been structured in ways compatible with state objectives, sequenced liberalisation is considered to be the most effective way to drive change: especially given the need for entrepreneurship we view as the best way to promote growth in green areas of the economy. This will require that state support is sectoral in its targeting and makes the deliberate effort to promote domestic competition to ensure efficiency concerns are not lost in the political structuring of economic activity.

A further principle requirement of the GGS will be that "given the way that existing unequal power relations tend to thwart fulsome policy debate and risk evaluation, it is necessary...to develop strategies of empowerment for systematically excluded groups to 
achieve more inclusive social deliberation" [62]. For this reason, we have proposed that multilevel, value-driven multi-stakeholder governance will be required to provide government institutions with the inclusive perspective needed to advance sustainable economic activity. This requirement is true at the level of participation below the state system, but also above in the international arena-as despite our concern to work from existing realities, there is clearly a need to build on these to prevent environmental negatives into the spaces between current governance arrangements.

A further necessary characteristic of the GGS is that it should actively promote trust and collaboration with wider society. Here the notion of "embedded autonomy" is useful in conceptualising an appropriate relationship, with high degrees of interaction between the state and key societal stakeholders. More broadly, it must be accepted that even where the state acts strongly, there must be resonance between its actions and the interests of wider society. For this reason, appropriate relations with key stakeholders and organisations help to construct interdependent networks that share the values and objective which underpin the Green Growth approach.

A fundamental focus on social justice operationalised in careful sequencing of transition, redistribution and support for stakeholder affected negatively in adjustment processes is also paramount. Finally, the state must ensure that appropriate tools for the measurement and evaluation of progress towards the Green Growth transition are established. While this is likely to require a reconsideration of GDP as the primary means of assessing national welfare potentials, other indicators must compliment this in key areas such as the growth of green infrastructure and direct welfare of the population.

Green growth needs to evolve as a concept to be adopted, as the discourse has shown. We have provided some necessary adaptations and requirements for the success of this new innovative social policy tool. There is a need to consider the integration of GGS and Critical 
Green Growth for true synergistic economic and environmental growth where both goals can and should be achieved simultaneously. We have shown ways to do this and in many cases examples exist, integrative thought, strategy, and adoption is needed for socially and environmentally beneficial outcomes to occur globally. 


\section{Bibliography}

[1] D. Tutu, We fought apartheid. Now climate change is our global enemy, in: The Guardian, London, 2014.

[2] J.A. Mathews, Green growth strategies-Korean initiatives, Futures, 44 (2012) 761-769.

[3] N. Kastrinos, The future of Britain's green growth, Futures, 27 (1995) 905-906.

[4] L. Elliott, Shades of green in East Asia: the impact of financial crises on the environment, Contemporary Politics, 17 (2011) 167-183.

[5] J. Meadowcroft, Greening the State, in: P.F. Steinberg, S.D. VanDeVeer (Eds.), Comparative Environmental Politics: Theory, Practice, and Prospects, 2012, pp. 63-87.

[6] D. Messner, J. Schellnhuber, S. Rahmstorf, D. Klingenfeld, The budget approach: A framework for a global transformation toward a low-carbon economy, Journal of Renewable Sustainable Energy, 2 (2010) 17-25.

[7] Terraviva Rio+20, Green Economy, the New Enemy, in, 2012.

[8] Rio+20, The Future We Want: Outcome document adopted at Rio+20, in, United Nations, 2013.

[9] J.A. Mathews, The renewable energies technology surge: A new techno-economic paradigm in the making?, Futures, 46 (2013) 10-22.

[10] M. Roelfsema, M.D. Elzen, N. Hohne, A.F. Hof, N. Braun, H. Fekete, H. Bottcher, R. Brandsma, J. Larkin, Are major economies on track to achieve their pledges for 2020? An assessment of domestic climate and energy policies, Energy Policy, 67 (2014) 781-796.

[11] R. Gouvea, S. Kassicieh, M.J.R. Montoya, Using the quadruple helix to design strategies for the green economy, Technological Forecasting \& Social Change, 80 (2013) 221-230.

[12] P.J. Partidario, J. Vergragt, Planning of strategic innovation aimed at environmental sustainability: actor-networks, scenario acceptance and backcasting analysis within a polymeric coating chain, Futures, 34 (2002) 841-861.

[13] P.J. Vergragt, A possible way out of the combined economic-sustainability crisis, Environmental Innovation and Societal Transitions, 6 (2013) 123- 125.

[14] C. Wilson, J. Tansey, S. Leroy, Integrating Backcasting \& Decision Analytic Approaches to Policy Formulation: A Conceptual Framework, The Integrated Assessment Journal Bridging Sciences \& Policy, 6 (2006) 143-164.

[15] L. Csaba, Green Growth - Mirage or Reality?, Intereconomics 13 (2010 ) 151-156.

[16] F. Schneider, G. Kallis, J. Martinez-Alier, Crisis or opportunity? Economic degrowth for social equity and ecological sustainability. Introduction to this special issue, Journal of Cleaner Production, 18 (2010) 511-518.

[17] D.A. Vazquez-Brust, J. Sarkis, Green-Growth: Managing the transition to sustainable capitalism - Learning by doing in East-Asia and Europe, Springer, London, 2012.

[18] F.H. Buttel, Ecological modernization as social theory, Geoforum, 31 (2000) 57-65.

[19] C. Death, The Green Economy in South Africa: Global Discourses and Local Politics, Politikon, 41 (2014) 1-22.

[20] I. Weibust, Green leviathan: the case for a federal role in environmental policy, Ashgate Publishing, Ltd., 2013.

[21] E. Urhammer, I. Ropke, Macroeconomic narratives in a world of crises: An analysis of stories about solving the system crisis, Ecological Economics 96 (2013) 62-70.

[22] Y. Glemarec, J.A.P.D. Oliveira, The role of the visible hand of public institutions in creating a sustainable future, Public Administration and Development, 32 (2012) 200-214.

[23] A. Cotugno, E. Seltzer, Towards a Metropolitan Consciousness in the Portland Oregon Metropolitan Area, International Planning Studies, 16 (2011) 289-304.

[24] A. Atkisson, A Fresh Start for Sustainable Development, Development, 56 (2013) 52-57. 
[25] H. Bulkeley, A. Jordan, R. Perkins, H. Selin, Governing sustainability: Rio+20 and the road beyond, Environment and Planning C: Government and Policy, 31 (2013) 958 - 970.

[26] M. Crivits, E. Paredis, P.-M. Boulanger, E.J.K. Mutombo, T. Bauler, A.-L. Lefin, Scenarios based on sustainability discourses: Constructing alternative consumption and consumer perspectives, Futures, 42 (2010) 1187-1199.

[27] S.-K. Rhee, D.-C. Jang, Y. Chung, A Critical Review and New Policy Framework of LowCarbon, Green-Growth Strategy of Korea, in: D.A. Vazquez-Brust, J. Sarkis (Eds.), Green Growth: Managing the Transition to a Sustainable Economy, Springer Netherlands, 2012, pp. 27-42.

[28] Heo, Changing aspects of government-society relations in South Korea: evidence from the evolution of environmental policy governance, Contemporary Politics, 19 (2013 ) 459-473.

[29] Ministry of Knowledge Economy, Industrial Stratergy for Green Grwoth, in, Ministry of Knowledge Economy, Soul, 2008.

[30] L. MacDonald, Main report. Vol. 1 of The East Asian miracle : economic growth and public policy. A World Bank policy research report, in, World Bank, Washington, DC, 1993.

[31] A. Almansoori, The influence of South Korean energy policy on OPEC oil exports, Energy Policy, 67 (2014) 572-582.

[32] K.-H. Choi, W. Oh, Extended Divisia index decomposition of changes in energy intensity: A case of Korean manufacturing industry, Energy Policy, 65 (2014) 275-283.

[33] J. Meadowcroft, Reaching the limits? Developed country engagement with sustainable development in a challenging conjuncture, Environment and Planning C: Government and Policy, 31 (2013) 988 - 1002.

[34] O. Bina, The green economy and sustainable development: an uneasy balance?, Environment and Planning C: Government and Policy, 31 (2013) 1023-1047.

[35] S. Lorek, J.H. Spangenberg, Sustainable consumption within a sustainable economy: beyond green growth and green economies, Journal of Cleaner Production, 63 (2014) 33-44.

[36] I. Watson, Contested meanings of environmentalism and national security in green Korea, The Pacific Review, 25 (2012 ) 537-560.

[37] T. Wanner, The New 'Passive Revolution' of the Green Economy and Growth Discourse: Maintaining the 'Sustainable Development' of Neoliberal Capitalism, New Political Economy, (2014).

[38] B.S.G. Devall, Deep ecology : living as if nature mattered, Peregrine Smith Books, Salt Lake City [i.e. Layton, Utah], 1985.

[39] A. Hamdouch, M.-H. Depret, Policy integration strategy of the 'green economy': foundations and implementation patterns, Journal of Environmental Planning and Management, 53 (2010) 473-490.

[40] R. Lane, The crisis from the point of view of evolutionary economics, International Journal of Social Economics, 37 (2010) 466-471.

[41] A. Martinelli, A. Midttun, Introduction: Towards green growth and multilevel governance, Energy Policy, 48 (2012) 1-4.

[42] UNEP, Green Jobs: Towards decent work in a sustainable, low-carbon world, in, UNEP, Nairobi, Kenya, 2008.

[43] J.S. Dryzek, The politics of the earth, environmental discourses, Oxford University Press, Oxford, 1997.

[44] P. Prasad, M. Elmes, In the name of the practical: Unearthing the hegemony of pragmatics in the discourse of environmental management, The Journal of Management Studies, 42 (2005) 845-867.

[45] D. Springett, Business conceptions of sustainable development: a perspective from critical theory, Business Strategy and the Environment, 12 (2003) 71-86. 
[46] Y. Glemarec, J.A. Puppim de Oliveira, The role of the visible hand of public institutions in creating a sustainable future, Public Administration and Development, 32 (2012) 200-214. [47] D.A. Vazquez-Brust, J. Sarkis, Green Growth: Managing the transition to sustainable economies, in: D.A. Vazquez-Brust, J. Sarkis (Eds.), Green-Growth: Managing the Transition to Sustainable Capitalism: Learning by doing in East-Asia and Europe, Springer, London, 2012.

[48] S. Fankhauser, A. Bowen, R. Calel, A. Dechezlepretre, D. Grover, J. Ryde, M. Sato, Who will win the green race? In search of environmental competitiveness and innovation, Global Environmental Change, 23 (2013) 902-913.

[49] R.J. Swart, P. Raskin, J. Robinson, The problem of the future: sustainability science and scenario analysis, Global Environmental Change, 14 (2004) 137-146.

[50] J.P. Holdren, Energy: Asking the wrong question, Scientific American, 286 (2002) 65-67. [51] J.A. Mathews, Naturalizing capitalism: The next Great Transformation, Futures, 43 (2011) 868-879.

[52] M. Jacobs, Green Growth, in: R. Falkner (Ed.), The Handbook of Global Climate Change and Enironmental Policy, John Wiley and Son, Chichester, 2013.

[53] A. Bowen, The green growth narrative: Paradigm shift or just spin?, Global Environmental Change, 21 (2011) 1157-1159.

[54] F. Alkemade, M. Hekkert, Coordinate Green Growth, Nature Geosci, 468 (2010) 897.

[55] S. Ambec, P. Lanoie, J. Laurent-Luchetti , N. Johnstone, Environment policy, innovation and performance: New insights on the Porter hypothesis Journal of Economics and Management Strategy, 20 (2011) 803-841.

[56] Y.M. C.S. Ho, L.W. Chau, B.T. Teh, J.J. Simson, K. Gomi, Blueprint for the development of low carbon society scenarios for Asian regions- case study of Iskandar Malaysia, Earth and Environmental Science, 16 (2013).

[57] H. Heidari, S.T. Katircioglu, L. Saeidpour, Economic growth, CO2 emissions, and energy consumption in the five ASEAN countries, Electrical Power and Energy Systems, 64 (2015) 785-791.

[58] L. Elliott, Shades of green in East Asia: the impact of financial crises on the environment, Contemporary Politics 17 (2011) 167-183.

[59] W. Li, D. Li, Environmental information transparency and implications for green growth in China, Public Administration and Development 32 (2012) 324-334.

[60] S. Zheng, M.E. Kahn, W. Sun, D. Luo, Incentives for China's urban mayors to mitigate pollution externalities: The role of the central government and public environmentalism, Regional Science and Urban Economics, 47 (2014) 61-71.

[61] H.E. Daly, The Economics of the Steady State, The American Economic Review, 64 (1974) 15-21.

[62] R. Eckersley, The Green State, MIT Press, Cambridge, Massachusetts, USA, 2004.

[63] Welsh Government, Sustainable Development: Our duty in, 2011.

[64] M. Woo-Cumings, The Developmental State, Cornell University Press, London 1999.

[65] A. Kohli, Where do high growth political economies come from? The Japanese lineage of Korea's "developmental state", World Development, 22 (1994) 1269-1293.

[66] A. Leftwich, Bringing politics back in: Towards a model of the developmental state, Journal of Development Studies, 31 (1995) 400 - 427.

[67] P.W. Kuznets, An East Asian Model of Economic Development: Japan, Taiwan, and South Korea, Economic Development and Cultural Change, 36 (1988).

[68] J.E. Stiglitz, Freefall: America, Free Markets, and the Sinking of the World Economy, Penguin, London, 2010.

[69] M. Piacentini, Rationale and policies for the green growth of cities and regional economies, International Economics and Economic Policy, 9 (2012) 129-146. 
[70] A. Midttun, The greening of European electricity industry: A battle of modernities, Energy Policy, 48 (2012) 22-35.

[71] F.W. Geels, The impact of the financial-economic crisis on sustainability transitions: Financial investment, governance and public discourse, Environmental Innovation and Societal Transitions, 6 (2013) 67- 95.

[72] H.-J. Chang, Kicking Away the Ladder - Development Strategy in Historical Perspective, Anthem Press, London, 2002.

[73] A.M. Smith, 'The Fair Trade Cup is 'Two-Thirds Full' not 'Two-Thirds Empty": A response to the Adam Smith report \& a new way to think about measuring the content of the fair trade Cup, in: Comment and Analysis, ESRC Centre for Business Relationships, Accountability, Sustainability and Society. Cardiff University, 2008.

[74] A.H. Amsden, Asia's Next Giant: South Korea and Late Industrialization

Oxford University Press, Oxford, 1989.

[75] R. Wade, Governing the Market: Economic Theory and the Role of Government in East Asian Industrialization, Princeton University Press, Princeton, 1990.

[76] B. Amable, The Diversity of Modern Capitalism, Oxford University Press, Oxford, 2003.

[77] C.A. Johnson, Miti and the Japanese Miracle: The Growth of Industrial Policy, Stanford University Press, Chicago 1982.

[78] D. Rodrik, Industrial Policy for the Twenty First Century, Paper prepared for UNIDO, September (2004).

[79] OECD, Green Growth: Overcoming the crisis and beyond, in, OECD Publishing, Paris, 2009.

[80] M. Jänicke, "Green growth": From a growing eco-industry to economic sustainability, Energy Policy, 48 (2012) 13-21.

[81] D.C. Mowery, R.R. Nelson, B.R. Martin, Technology Policy and Global Warming: Why new policy models are needed (or why putting new wine in old bottles won't work), Research Policy, 6 (2010) 36-76.

[82] H. Kim, R. Stech, Greening the Korean stacks through lessons from the EU Emissions Trading System: a socio-legal analysis, in: D.A. Vazquez-Brust, J. Sarkis (Eds.), GreenGrowth: Managing the Transition to Sustainable Capitalism: Learning by doing in East-Asia and Europe, Springer, London, 2012.

[83] D. Fouquet, T.B. Johansson, European renewable energy policy at crossroads-Focus on electricity support mechanisms, Energy Policy, 36 (2008) 4079-4092.

[84] R. Schleicher-Tappeser, How renewables will change electricity markets in the next five years, Energy Policy, 48 (2012) 64-75.

[85] HSBC, A Climate for Recovery The colour of stimulus goes green, in, 2009.

[86] Y.G. Lee, Strengthening competency linkage to innovation at Korean universities, Scientometrics, 90 (2012) 219-230.

[87] L. Mez, Nuclear energy-Any solution for sustainability and climate protection?, Energy Policy, 48 (2012) 56-63.

[88] C. Böhringer, U. Moslener, U. Oberndorfer, A. Ziegler, Clean and productive? Empirical evidence from the German manufacturing industry, Research Policy, 41 (2012) 442-451.

[89] S. Schneider, Global Warming: Neglecting the complexities, Scientific American, 286 (2002) 62-65.

[90] A. Morley, R. Sonnino, A.M. Smith, Leading by Procuring: The Power of Public Sector Purchasing, in: D.R. Gallaghe (Ed.), Environmental Leadership: A Reference Handbook, SAGE Publications, London, 2012.

[91] D. Reiche, M. Bechberger, Policy differences in the promotion of renewable energies in the EU member states, Energy Policy, 32 (2004) 843-849. 
[92] A. Damonte, Policy tools for green growth in the EU15: a Qualitative Comparative Analysis,, Environmental Politics,, 23 (2014 ) 18-40.

[93] D.A. Vazquez-Brust, J. Sarkis, Green-Growth: Managing the Transition to Sustainable Capitalism: Learning by doing in East-Asia and Europe, Springer, London, 2012.

[94] A.K. Sen, Democracy as a Universal Value, Journal of Democracy 10 (1999) 3-17

[95] J. Habermas, Between Facts and Norms: Contributions to a discourse theory of law and democracy, MIT Press, Cambridge, MA, 1996.

[96] K. Backstrand, J. Kahn, A. Kronsell, E. Lovbrand, Environmental Politics and Deliberative Democracy: Examining the promise of new modes of governance, Edward Elgar, Cheltenham, 2011.

[97] S. Christopoulos, B. Horvath, M. Kull, Advancing the governance of cross-sectoral policies for sustainable development: A metagovernance perspective, Public Administration and Development, 32 (2012) 305-323.

[98] G. Seyfang, A. Smith, Grassroots Innovations for Sustainable Development: towards a new research and policy agenda, Environmental Politics, 16 (2007) 584-603.

[99] M. Pansera, Innovation System for sustainability in developing countries. The renewable energy sector in Bolivia, International Journal of Innovation and Sustainable Development, 7 (2013) 27-45.

[100] W. Li, D. Li, Environmental information transparency and implications for green growth in china, Public Administration and Development, 32 (2012) 324-334.

[101] K. Morgan, R. Sonnino, The urban foodscape: world cities and the new food equation, Cambridge Journal of Regions, Economy and Society, 3 (2010) 209-224.

[102] P. Dicken, Global shift: mapping the changing contours of the world economy, Sage, London, 2007.

[103] S.-K. Rhee, D.-c. Jang, Y. Chung, A Critical Review and New Policy Framework of Low-Carbon, Green Growth Strategy of Korea, in: D.A. Vazquez-Brust, J. Sarkis (Eds.), Green Growth: Managing the transition to sustainable economies, London, 2012.

[104] P. Meyfroidt, E.F. Lambin, Forest transition in Vietnam and displacement of deforestation abroad, Proceedings of the National Academy of Sciences, 106 (2009) 1613916144.

[105] T. Kastner, K.-H. Erb, S. Nonhebel, International wood trade and forest change: A global analysis, Global Environmental Change, 21 (2011) 947-956.

[106] B. Lomborg, The Skeptical Environmentalist: Measuring the real state of the world, Cambridge University Press, Cambridge, 2001.

[107] T.A. Branch, O.P. Jensen, D. Ricard, Y. Ye, R.A.Y. Hilborn, Contrasting Global Trends in Marine Fishery Status Obtained from Catches and from Stock Assessments

Contraste de las Tendencias Globales en el Estatus de las Pesquerías Marinas Obtenido de Capturas y Evaluación de Reservas, Conservation Biology, 25 (2011) 777-786.

[108] A.K. Chapagain, A.Y. Hoekstra, H.H.G. Savenije, R. Gautam, The water footprint of cotton consumption: An assessment of the impact of worldwide consumption of cotton products on the water resources in the cotton producing countries, Ecological Economics, 60 (2006) 186-203.

[109] A. Jordan, D. Liefferink, J. Fairbrass, TheEuropeanisationofNational Enviromental Policy:acomparativeanalysis, in: J. Barry, B. Baxter, R. Dunphy, J. Fairbrass (Eds.), Europe Globalisation and Sustainable Development, Routledge, London, 2004.

[110] D. Held, Democracy and the Global Order: From the Modern State to Cosmopolitan Governance, Stanford University Press, Stanford, California, USA, 1995.

[111] N. Kanie, M.M. Betsill, R. Zondervan, F. Biermann, O.R. Young, A charter moment: Restructuring governance for sustainability, Public Administration and Development, 32 (2012) 292-304. 
[112] D.F. Thompson, Democratic Theory and Global Society, Journal of Political Philosophy, 7 (1999) 111-125.

[113] OECD, OECD Environmental Outlook to 2050: The Consequences of Inaction, in, Meeting of OECD Environment Ministers, 2012.

[114] H.W.-c. Yeung, Governing the market in a globalizing era: Developmental states, global production networks and inter-firm dynamics in East Asia, Review of International Political Economy, (2013) 1-32.

[115] R.S. Jones, S. Urasawa, Promoting Social Cohesion in Korea, in: OECD Economics Department Working Papers, OECD Publishing, 2012.

[116] D. Resnick, F. Tarp, J. Thurlow, The Political Economy of Green Growth: Cases from Southern Africa, Public Administration and Development, 32 (2012) 215-228.

[117] P.B. Evans, Embedded Autonomy: States and Industrial Transformation, Princton University Press, New Jersey, 1995.

[118] T.J. Newton, Creating the New Ecological Order? Elias and Actor Network Thoery, Academy of Management Review, 27 (2002).

[119] P. Evans, Government action, social capital and development: Reviewing the evidence on synergy, World Development, 24 (1996) 1119-1132.

[120] L. Backer, When oil and wind turbine companies make green sense together, Business Strategy and the Environment, 18 (2009) 43-52.

[121] S. El Serafy, Green accounting and economic policy, Ecological Economics, 21 (1997) 217-229.

[122] J. Stiglitz, A. Sen, J.-P. Fittosi, Miss-measuring our Lives: Why GDP does not add up, New York Press, New York, 2010.

[123] R.K. Singh, H.R. Murty, S.K. Gupta, A.K. Dikshit, An overview of sustainability assessment methodologies, Ecological Indicators, 15 (2012) 281-299.

[124] D. Meadows, Indicators and Information Systems for Sustainable Development - A Report to the Balaton Group, in, The Sustainability Institute, Hartland, USA, 1998.

[125] P. Bartelmus, The future we want: Green growth or sustainable development?, Environmental Development, 7 (2013) 165-170.

[126] T.-W. Han, G.-S. Kim, D. Lim, Green Growth Index and Policy Feedback, in: D.A. Vazquez-Brust, J. Sarkis (Eds.), Green-Growth: Managing the Transition to Sustainable Capitalism: Learning by doing in East-Asia and Europe, Springer, London, 2012.

[127] J. Randers, Greenhouse gas emissions per unit of value added ("GEVA") - A corporate guide to voluntary climate action, Energy Policy, 48 (2012) 46-55.

[128] UNEP, Metrics \& Indicators, in: Briefing Paper, 2012.

[129] L.J. Lundqvist, A Green Fist in a Velvet Glove: The Ecological State and Sustainable Development, Environmental Values, 10 (2001) 455-472. 
